\title{
Q.
QNEEN'S
UNIVERSITY
BELFAST
}

\section{Design and Flux-Weakening Control of an Interior Permanent Magnet Synchronous Motor for Electric Vehicles}

Zhang, Y., Cao, W., McLoone, S., \& Morrow, J. (2016). Design and Flux-Weakening Control of an Interior Permanent Magnet Synchronous Motor for Electric Vehicles. IEEE Transactions on Applied Superconductivity, 26(7), [0606906]. https://doi.org/10.1109/TASC.2016.2594863

\section{Published in:}

IEEE Transactions on Applied Superconductivity

\section{Document Version:}

Peer reviewed version

Queen's University Belfast - Research Portal:

Link to publication record in Queen's University Belfast Research Portal

\section{Publisher rights}

Copyright 2017 IEEE - All rights reserved.

This work is made available online in accordance with the publisher's policies. Please refer to any applicable terms of use of the publisher.

\section{General rights}

Copyright for the publications made accessible via the Queen's University Belfast Research Portal is retained by the author(s) and / or other copyright owners and it is a condition of accessing these publications that users recognise and abide by the legal requirements associated with these rights.

Take down policy

The Research Portal is Queen's institutional repository that provides access to Queen's research output. Every effort has been made to ensure that content in the Research Portal does not infringe any person's rights, or applicable UK laws. If you discover content in the Research Portal that you believe breaches copyright or violates any law, please contact openaccess@qub.ac.uk. 


\title{
Design and Flux-Weakening Control of an Interior Permanent Magnet Synchronous Motor for Electric Vehicles
}

\author{
Yue Zhang, Student Member, IEEE, Wenping Cao, Senior Member, IEEE, Sean McLoone, Senior Member, IEEE \\ and John Morrow, Member, IEEE
}

\begin{abstract}
Permanent magnet synchronous motors (PMSMs) provide a competitive technology for $\mathrm{EV}$ traction drives owing to their high power density and high efficiency. In this paper, three types of interior PMSMs with different PM arrangements are modeled by the finite element method (FEM). For a given amount of permanent magnet materials, the $V$ shape interior PMSM is found better than the U-shape and the conventional rotor topologies for $\mathrm{EV}$ traction dri ves. Then the $\mathrm{V}$ shape interior PMSM is further analyzed with the effects of stator slot opening and the permanent magnet pole chamfering on cogging torque and output torque performance. A vector-controlled fluxweakening method is developed and simulated in matlab to expand the motor speed range for $\mathrm{EV}$ drive system. The results show good dynamic and steady-state performance with a capability of expanding speed up to 4 times of the rated. A prototype of the $V$ shape interior PMSM is also manufactured and tested to validate the numerical models built by the finite element method.
\end{abstract}

Index Terms-Electrical vehicles (EVs), finite element method (FEM), permanent magnet synchronous motors (PMSMs), torque ripple, flux weakening.

\section{INTRODUCTION}

$\mathrm{E}$ LECTRIFIED VEHICLES (EVs) have been considered as a major technical advancement over conventional fossil fuel based vehicles, because of their low emissions and high efficiency [1]-[3]. At the heart of EV drivetrain is the electrical motor, which converts electricity (generally from a battery) into mechanical energy to drive the wheels. The motor drives can be based on direct-current (DC) motors, induction motors (IMs), switch reluctance motors (SRMs), permanent magnet synchronous motors (PMSMs), switched flux permanent magnet motors (SFPMMs) [4]. In the literature, different motor topologies for EVs are compared [5]-[8] and results show that PMSMs have the best performance in terms of system efficiency, power density and power-speed range while their drawbacks are associated with limited reserve and

Automatically generated dates of receipt and acceptance will be placed here; authors do not produce these dates. This work was supported by Royal Society, UK and National Natural Science Foundation, China under Grant 5141101208. (Corresponding author: YueZhang.)

Yue Zhang, Sean McLoone and John Morrow are with the School of Electronics, Electrical engineering and Computer Science, Queens University Belfast, Belfast,BT95AH,UK (e-mail: yzhang35@qub.ac.uk).

Wenping Cao is now with the Power Electronics, Machines, and Power System group, Aston University, Birmingham, B4 7ET, UK supply stability of the rare-earth materials they rely on. Although both interior PMSMs and surface mounted PMSMs can be utilized for EV traction drives, the former are more suitable for EV traction drives [9] as they can offer higher reliability and overload ability than the latter.

Within interior PMSMs, There are various rotor topologies available, which offer some flexibility and design freedom with regard to the placement of permanent magnets. Rotor topologies and parameters can lead to differing performance of EV motor drives. A multi-objective optimization approach for the interior PMSM design is proposed in [10], with the response surface methodology introduced to dramatically save the CPU-time without de-grading accuracy. Moreover, torque ripple reduction of interior PMSMs has also attracted much attention as noise and vibration can be issues that affect drive comfort. An optimization of rotor slot geometry is proposed in [11]. Rotor pole skewing is adopted in [12] and the current harmonic injection is employed in [13]. Alternatively, a genetic algorith $m$ approach with efficient FEM is proposed to minimize cogging torque for PMSMs [14].

For EV traction applications, a wide speed range is highly desirable. Interior PMSMs can extend their operational speed range by weakening their magnetic flux (constant power operation). Moreover, other methods proposed in the literature include magnet segmentation and rotor iron bridge dimension optimization. Both are proved to be effective in improving the motor's flux weakening capability [15].

In this paper, three types of interior PM topologies are analyzed and compared. Based on the same amount of permanent magnet material used, the salient rate is altered to find the most suitable interior PMSM topology for EV traction drives. The magnetic cross- coupling effect has been taken into consideration to increase the calculation precision. The PMSM with a V-shape rotor magnet is chosen and researched further (e.g. inductance, slot opening, permanent magnet chamfering) to compare the effectiveness of torque ripple reduction. Then a flux-weakening vector-control drive system is built in Matlab to provide a control scheme for high-speed operation. A V-shape rotor PMSM is finally prototyped and experimentally tested to verify the developed numerical models.

\section{ROTOR TOPOLOGIES}

For PMSMs, the permanent magnet can be positioned in the rotor laminations as "U" shape, "V" shape and conventional 
shape. Three typical motor topologies are shown in Fig.1, while the motor specifications are listed in Table I. The following assumptions are made in order to compare different motor topologies: i) the stator, shaft, air gap and windings are identical; ii) the same a mount of permanent magnet material is utilized; iii) the distance between the rotor slot (which containing the permanent magnet) outer edge and the shaft center is identical (namely, same magnetic insulation bridge size).

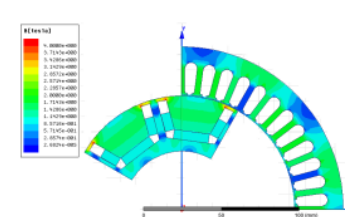

(a)

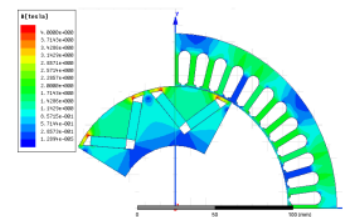

(b)

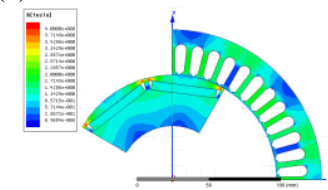

(c)

Fig. 1. Magnetic field distribution at no-load condition (a) U shape rotor (b) Vshape rotor(c) Conventional shape rotor.

TABLEI

Motor SPECIFICATIONS

\begin{tabular}{|c|c|}
\hline Parameter & Value \\
\hline Power & $20 \mathrm{~kW}$ \\
\hline Rated Voltage (amplitude) & $85 \mathrm{~V}$ \\
\hline Rated speed & $2000 \mathrm{rpm}$ \\
\hline No. of pole pairs & 4 \\
\hline Stat or out er diameter & $210 \mathrm{~mm}$ \\
\hline Stator inner diameter & $148 \mathrm{~mm}$ \\
\hline Rotor outer diameter & $146.6 \mathrm{~mm}$ \\
\hline Stack length & $88 \mathrm{~mm}$ \\
\hline
\end{tabular}

In general, interior PMSMs can be analyzed under the rotating synchronous frame, as the stator windings are energized by $\mathrm{d}$ axis current $i_{d}$ and $q$ axis current $i_{q}$ respectively, The motor performance can be described by the inductances $\mathrm{L}_{d}$ and $\mathrm{L}_{\mathrm{q}}$. Due to the magnetic cross- coupling effect between the magnetic flux path in the $\mathrm{d}$ axis and $\mathrm{q}$ axis, accurate calculation of inductance parameters should take it into consideration. Therefore the FEM can be utilized as below to obtain inductance parameters:

$$
\begin{gathered}
\psi_{P M}\left(i_{q}\right)=\psi_{d}\left(i_{d}=0, i_{q}\right) \\
L_{d}\left(i_{d}, i_{q}\right)=\frac{\psi_{d}\left(i_{d}, i_{q}\right)-\psi_{P M}\left(i_{q}\right)}{i_{d}} \\
L_{q}\left(i_{d}, i_{q}\right)=\frac{\psi_{q}\left(i_{d}, i_{q}\right)}{i_{q}}
\end{gathered}
$$

where $\Psi_{\mathrm{d}}$ and $\Psi_{\mathrm{q}}$ are the flux linkage in $\mathrm{d}$ axis and $\mathrm{q}$ axis, respectively, and $\Psi_{P M}$ is the flux linkage excited by the permanent magnet alone [16]. The saliency of the interior PMSM can be described by the salient rate, which is the ratio of the q axis inductance $L_{q}$ over the d axis inductance $L_{d}$. The saliency of the rotor can drastically change the motor performance, especially at high-speed flux-weakening conditions [17].

For the three interior PMSMs, a current source is employed as power supply and the salient rate under different $d$ axis and $\mathrm{q}$ axis current are obtained, as shown in Fig. 2 to4.

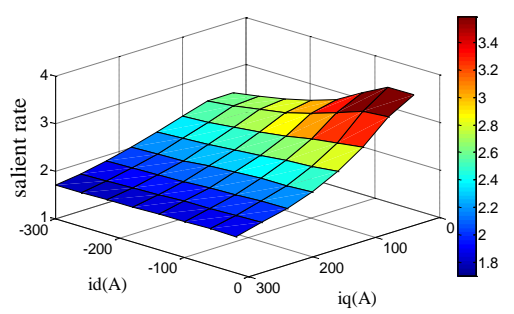

Fig. 2. U shape rotor motor

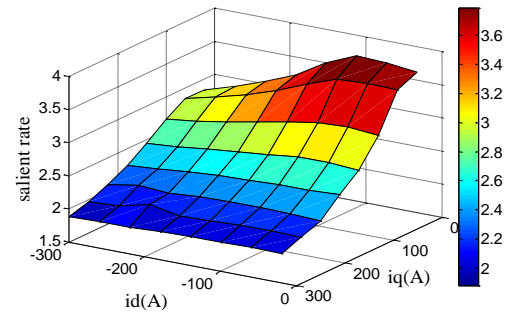

Fig. 3. V shape rotor motor

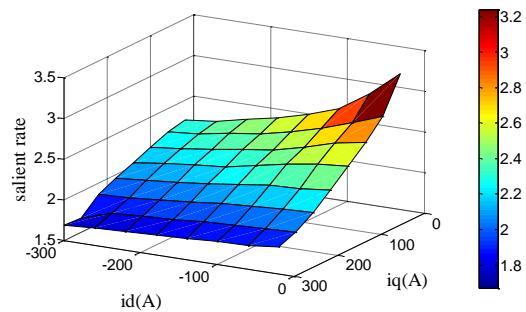

Fig. 4. conventional shape rotor motor

It can be observed that the salient rate is affected by both $i_{d}$ and $\mathrm{i}_{\mathrm{q}}$ with similar trends but at a different level due to the difference in magnetic path in the three motors. The salient rate decreases as q axis current increases, however, such trend is not obviously observed when a high $\mathrm{d}$-axis current is applied. This is owing to the magnetic couple effect between the $\mathrm{d}$-axis and q-axis magnetic field. At almost all the working points, the V-shape rotor motor has the highest salient rate, indicating the largest saliency torque when the same power supply is applied. The V-shape interior PMSM can be controlled with a wide constant-power region, which is highly valued in $\mathrm{EV}$ traction drives.

\section{TORQUE RIPPLE REDUCTION}

It is ideal that EV traction motors have low cogging torque, torque ripple and high power density. The cogging torque in PMSMs is formulated as [18]:

$$
T_{c o g}(\alpha)=\frac{\pi z L_{e f}}{4 \mu_{0}}\left(R_{2}^{2}-R_{1}^{2}\right) \sum_{n=1}^{\infty} n G_{n} B_{r \frac{n z}{2 p}} \sin n z \alpha
$$

Where $a$ is the rotation angle, $z$ is the slot number, $L_{e f}$ is the axial length of armature, $R_{1}$ is the outer radius of rotor, $R_{2}$ is the inner radius of armature, $G_{n}$ is the $\mathrm{n}^{\text {th }}$ Fourier transform 
coefficient of the permanent magnet geo metry parameter, $B_{r}$ is the air gap flux density in an equivalent slotless motor. An analytical method based on a virtual PM concept and the superposition principle for calculation of the cogging torque of interior PMSMs with multi flux barriers in the rotor is illustrated in [19]. While the PM motor torque ripple can be expressed as [20]:

$$
T_{\text {ripple }}=-\frac{P \mu_{0}}{2 g} r_{g} l_{s t k} \pi^{*} \sum_{\substack{h=6 m \neq 1 \\ m=1,2,3 \ldots \ldots}}\left(h f_{s, h} f_{r, h} \sin \left((h \pm 1) \omega_{e} t \pm \lambda_{d}\right)\right)
$$

Where $P$ is the number of poles, $r_{\mathrm{g}}$ is the air gap radius, $l_{\mathrm{stk}}$ is the stack length, $f_{\mathrm{s}, \mathrm{h}}, f_{\mathrm{r}, \mathrm{h}}$ are the $\mathrm{h}^{\text {th }}$ stator and rotor MMF harmonics, respectively. It can be observed that the motor torque ripple is relative to the high order harmonic components in the MMF. The V-shape rotor interior PMSM is analyzed by FEM and the motor winding $d$ axis and $q$ axis inductances at rated load in one electrical period are shown in Fig.5.

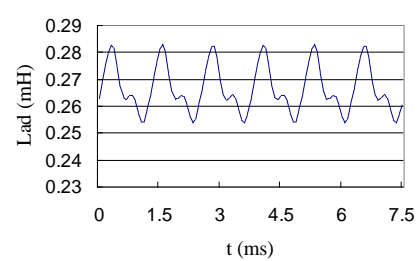

(a)

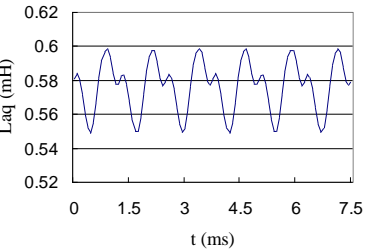

(b)
Fig. 5. The d- and q- axis inductances. (a) d-axis inductance. (b) q-axis inductance

As the existence of harmonic components in inductances, the torque ripple is always present. In order to decrease the cogging torque and torque ripple for the $\mathrm{V}$-shape interior PMSM, the stator and rotor parameter configurations can be adjusted accordingly.

\section{A. Effect of Stator Slot Opening}

The cogging torque (peak to peak), torque ripple (peak to peak) and average torque of the V-shape interior PMSM at rated voltage as a function of slot opening width are presented in Fig.6.

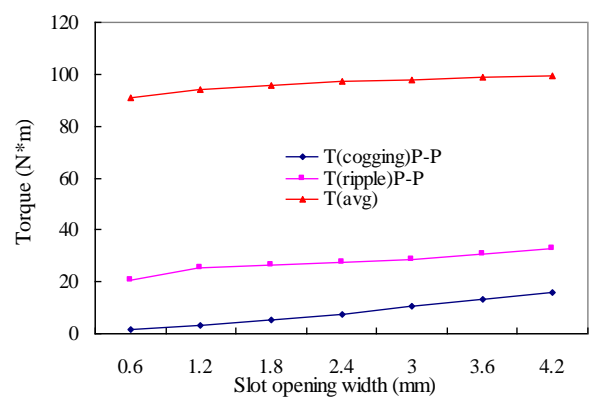

Fig. 6. Variation of cogging torque, torque ripple and average torque

As the slot opening width decreases, both the cogging torque and torque ripple in interior PMSM are reduced. Clearly, the slot opening width impacts mainly on cogging torque. For instance, the cogging torque reduces by $90 \%(1.5 \mathrm{Nm}$ at 0.6 $\mathrm{mm}$ slot open width and $15.6 \mathrm{Nm}$ at the $4.2 \mathrm{~mm}$ s lot open width) while the torque ripple reduces by $37 \%(20.8 \mathrm{Nm}$ at $0.6 \mathrm{~mm}$ slot open width and $32.9 \mathrm{Nm}$ at the $4.2 \mathrm{~mm}$ slot open width). The average torque is slightly affected by the increase in the slot opening width and it gives rise to the magnetic path reluctance.

\section{B. Magnetic Pole Chamfering}

The pole chamfering method for each chunk of permanent magnets for the V-shape interior PMSM is shown inFig.7, where $a$ denotes the pole chamfering width:

Fig. 7. Magnetic pole chamfering

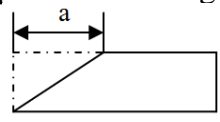

By changing the chamfering width, the average torque, torque ripple (peak to peak) and cogging torque (peak to peak) can be altered, as shown in Fig.8.

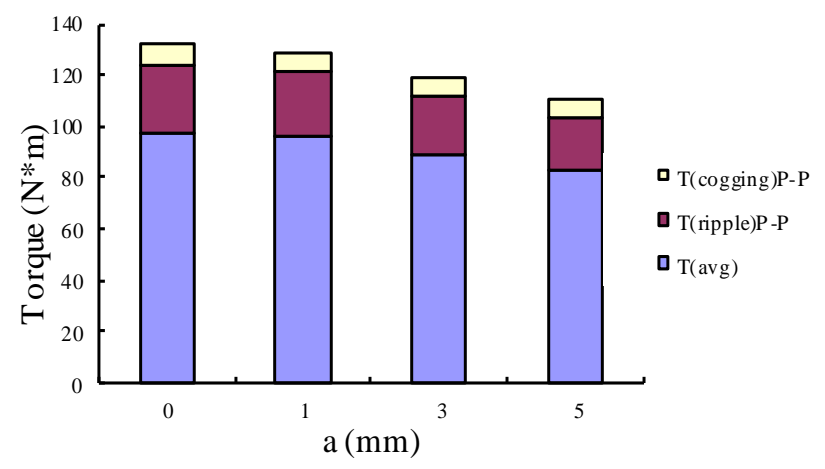

Fig. 8. Variation of cogging torque, torque ripple and average torque

From Fig. 8 it can be seen that the pole chamfering can also impacts on the cogging torque and especially the torque ripple. By changing $a$ from 0 to $5 \mathrm{~mm}$, the torque ripple can be reduced by $4.3 \mathrm{~N}^{*} \mathrm{~m}$. As the average torque is also affected, it is necessary to strike a balance between the output torque and torque ripple when adopting the pole chamfering method for interior PMSMs.

\section{FLUX-WEAKENING CONTROL}

Due to the limitation of the converter capability, flux weakening is a commonly-accepted scheme to expand the speed range beyond rated for interior PMSMs. This is achieved by adjusting the $i_{d}$ current to cancel out some magnetic field produced by permanent magnets.

In this paper, a vector control drive system is designed and simulated in Matlab. It consists of two operational modes: constant torque mode and constant power mode. The constant torque mode is for the motor running at a speed lower than the rated speed (2000 $\mathrm{rpm}$ in this case). The motor is controlled to generate the maximu m torque with the least current below this speed while the constant power mode is for the motor running at speeds higher than the rated speed (flux weakening operation). The developed control drive system is schematically shown in Fig. 9: 


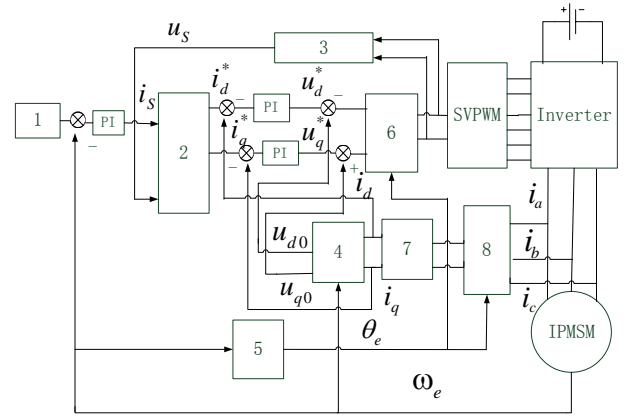

Fig. 9. The PMSM flux weakening control.

1) Reference speed. 2) Flux weakening block. 3) Voltage calculation.

4) Decoupling block. 5) Integration. 6) Inverse Park transform.

7) Clark transform. 8) Park transform.

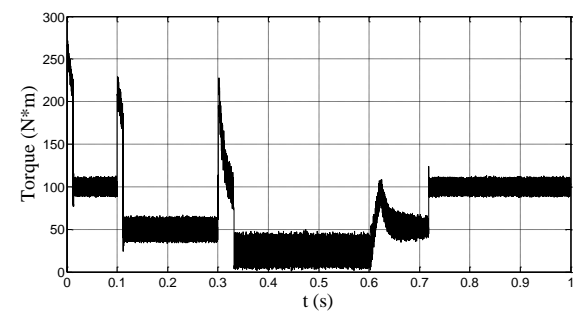

Fig. 10. Torque response.

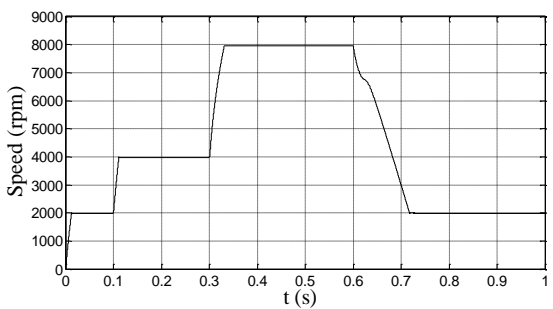

Fig. 11. Speed response.

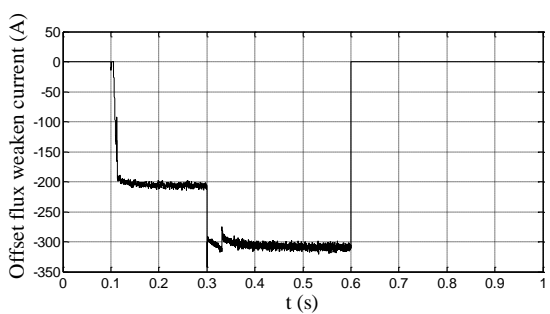

Fig. 12. Offset flux weakening current.

The PMSM drive is controlled via two closed loops: a speed loop and a current loop; a special PI controller is utilized in the flux weakening block: if the motor reference speed is lower than the flux weakening speed (rated speed), the PI controller saturates with no offset flux weakening current produced. Once the actual motor reference speed is higher than the flux weakening speed, a negative flux weakening current is produced by the PI controller to reduce the flux as per the speed extension requirements. The offset flux weakening current is a current added to the $\mathrm{d}$ axis current to decrease the flux density for the motor under flux-weakening operation. At $0 \mathrm{~s}$, the load is $100 \mathrm{Nm}$ and the reference speed is set at $2000 \mathrm{rpm}$. At $0.1 \mathrm{~s}$ the motor load decreases to $50 \mathrm{Nm}$ and the reference speed is up to $4000 \mathrm{rpm}$. After $0.3 \mathrm{~s}$, the reference speed is set at $8000 \mathrm{rpm}$ and the load is decreased to $25 \mathrm{Nm}$. At
$0.6 \mathrm{~s}$, the load returns to $100 \mathrm{Nm}$ and the reference speed is back to 2000rpm. The corresponding motor responses are shown in Figs. 10-12. It can be seen that if the motor speed is below the flux weakening speed $2000 \mathrm{rpm}$, the offset flux weakening current is zero. As the motor speed is higher than $2000 \mathrm{rpm}$, the flux weakening block acts dynamically and produces the flux weakening current through the PI controller based on actual motor speed. The drive system operates in flux weakening mode to expand the speed range. The whole control drive system has shown good dynamic and steady performance in response to speed and load variations with capability of expanding the speed range up to 4 times, which is suited for $\mathrm{EV}$ traction drives.

\section{EXPERIMENT}

The back electromotive force (EMF) is a key parameter to evaluate the motor efficiency and torque performance. So the distance between the two magnets of neighboring poles (denoted L in Fig. 13) can be adjusted. Table II shows the EMF fundamental component amplitude and its proportion in the whole spectrum as a function of $L$.

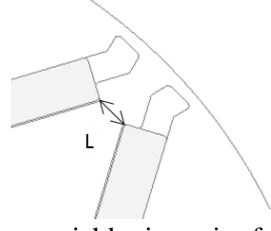

Fig. 13. Distance between a neighboring pair of poles

TABLE II

Motor EMF Fundamental COMPONENT PROPORTION

\begin{tabular}{cccccc}
\hline \hline $\mathrm{L}(\mathrm{mm})$ & 2 & 3 & 4 & 5 & 6 \\
$\begin{array}{c}\text { Fundamental } \\
\text { amplitude (V) }\end{array}$ & $66.43 \mathrm{~V}$ & $69.49 \mathrm{~V}$ & $71.97 \mathrm{~V}$ & $74.49 \mathrm{~V}$ & $77.13 \mathrm{~V}$ \\
Proportion & $97.81 \%$ & $97.32 \%$ & $96.64 \%$ & $95.85 \%$ & $95.20 \%$ \\
\hline \hline
\end{tabular}

It can be seen that, as $L$ increases, the fundamental amplitude increases but its proportion in the whole spectrum decreases. So a compromise should be achieved. Moreover, L cannot be set too large as it may decreases the length of magnetic insulation bridge and reduces the rotor core mechanical strength in high speed operation.

Following a numerical study, a $20 \mathrm{~kW}$ V-shape interior PMSM for EVs is prototype. The photographs of its stator and rotor are shown in Fig. 14.

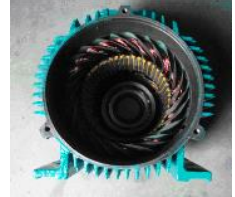

(a)

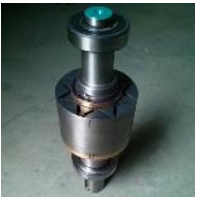

(b)
Fig. 14. Photographs of the prototype machine. (a) The stator. (b) The rotor.

Fig. 15 (a) presents the measured phase back EMF over one electrical cycle under rated speed under no load, as compared to numerical results by FEM. It is observed that the two results agree well with each other; while Fig. 15 (b) shows 
the fundamental amplitudes of measured EMFs at different motor speeds. Clearly, experimental tests have validated numerical models used for motor performance analysis.

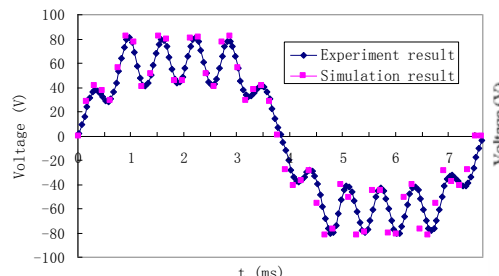

(a)

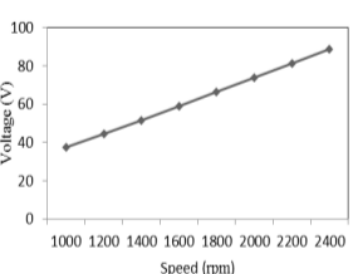

(b)
Fig.15. Experimental results (a) Comparison of experimental and numerical results for EMF (b) EMF fundamental amplitude under different speed

\section{CONCLUSION}

In this paper, the saliency of three different interior PMSM topologies considering the magnetic cross-coupling effect is investigated. Simulation results suggest that V-shape interior PMSMs have a higher salient rate than other types for EVs. The torque ripple is next investigated by FEM and it can be minimized by shortening the slot opening width and magnetic pole chamfering. Similarly, the cogging torque can be dramatically suppressed by reducing the slot opening. Moreover, the motor capability to expand the speed range up to 4 times has been achieved by the designed flux weakening drive system. The effectiveness of the simulation models has been also experimentally validated by testing a prototype motor.

\section{REFERENCES}

[1] C. C. Chan, "The state of the art of electric, hybrid and fuel cell vehicles," Proc. IEEE, vol. 95, no.4, Apr. 2007, pp. 704-718.

[2] C. C. Chan, A. Bouscayrol, and K.Chen, "Electric, Hybrid, and fuel cell vehicles: Architectures and modeling," IEEE Trans. Veh. Technol. vol. 59, no.2, Feb. 2010, pp. 589-598.

[3] V.T. Buyukdegirmenci, A. M. Bazzi, and P.T. Krein, " Evaluation of induction and permanent magnet synchronous machine using drive-cycle energy and loss minimization in traction applications," IEEE Trans. Ind. Appli, vol. 50, no.1, Feb. 2014, pp. 395-403.

[4] Z. Q. Zhu and D. Howe, "Electrical machines and drives for EV electric, hybrid and fuel cell vehicles" Proc. IEEE, vol. 95, no.4, Apr. 2007, pp. $746-765$.

[5] X. Liu, Z. Q. Zhu, and D.Wu, "Evaluation of efficiency optimized variable flux reluctance machine for EVs/ HEVs by comparing with interior PM Machine," in Proc. IEEE ICEMS, Hangzhou, China, 2014, pp. 2648-2654.

[6] J. Joss, M. Popesuc, and D.Staton, “ A Comparison of an interior permanent magnet and copper rotor induction motor in a hybrid electric vehicle application," in Proc. IEEE IEMDC, Chicago, USA, 2013, pp. 220-225.

[7] G. Pellegrino, A. Vagati, B. Boazzo and P. Guglielmi, "Comparison of induction and PM synchronous motor drives for EV application including design examples," IEEE Trans. Ind. Appli, vol. 48, no.6, Nov. 2012, pp. 2322-2332.

[8] D. G. Dorrell, A. M. Knight and M. Popescu "Comparison of different motor design drives for hybrid electric vehicles," in Proc. IEEE ECCE, Atlanta, USA, 2010,pp. 3352-3359.

[9] J. H. Seo and H. S. Choi, "Cogging torque calculation for IPM having single layer based on magnetic circuit model," IEEE Trans. Mag, vol. 50, no.10, Oct. 2014, Art. ID 8102104.

[10] Y. Fujishima, S. Wakao and M. Kondo, "An optimal design of interior permanent magnet synchronous motor for the next generation commuter train,” IEEE Trans. Appl. Supercond., vol. 14, no. 2, Jun. 2004, pp. 1902-1905.

[11] U. Seo, Y. Chun and J. Choi, "A technique of torque ripple reduction in interior permanent magnet synchronous motor," IEEE Trans. Mag, vol. 47, no.10, Oct. 2011, pp. 3240-3243.

[12] W. Q. Chu and Z. Q. Zhu, "Reduction of on -load torque ripples in permanent magnet synchronous machine by improved skewing," IEEE Trans. Mag, vol. 49, no.7, Jul. 2013, pp. 3822-3825.

[13] G. H. Lee, S. I. Kim and J. P. Hong, "Torque ripple reduction of interior permanent magnet synchronous motor using harmonic injected current," IEEE Trans. Mag, vol.44, no.6, June. 2008, pp. 1582-1585.

[14] S. L. Ho, N. Chen and W. Fu, "An optimal design method for the minimization of cogging torques of a permanent magnet motor using FEM and Genetic algorithm," IEEE Trans. Appl. Supercond., vol. 20, no. 3, Jun. 2010, pp. 861-864.

[15] S. Duan, L. Zhou and J. Wang, "Flux weakening mechanism of interior permanent magnet synchronous machines with segmented permanent magnets," IEEE Trans. Appl. Supercond., vol. 24, no. 3, Jun. 2014, Art. ID. 0500105 .

[16] G. Qi, J. T. Chen and Z. Q. Zhu, "Influence of skew and cross coupling on flux weakening performance of permanent magnet brushless AC machines," IEEETrans. Mag, vol. 45, no.5, May. 2009, pp. 21 10-2117.

[17] K. Kim, J. Lee and H.Kim "Multi-objective optimal design for interior permanent magnet synchronous motor," IEEE Trans. Mag, vol. 45, no.3, Mar. 2009, pp. 1780-1783.

[18] D. Wang, X. Wang and Y. Y, "Optimization of magnetic pole shifting to reduce cogging torque in solid rotor permanent magnet synchronous motors," IEEE Trans. Mag, vol. 46, no.5, May. 2010, pp. 1228-1234.

[19] J.Seo and H. Choi, "Analytical modeling for calculating cogging torque in interior permanent magnet machine with multi flux-barriers," IEEE Trans. Appl. Supercond., vol. 24, no. 3, Jun. 2014, Art. ID. 0503904.

[20] S. Han, T. Johns, "Torque ripples reduction in interior permanent magnet synchronous machines using stators with odd number of slots per pole pair," IEEE Trans. Ene Cov, vol. 25, no.1, Jan. 2010, pp. 118127. 